This article was downloaded by: [UNISA University South Africa]

On: 11 January 2012, At: 03:41

Publisher: Routledge

Informa Ltd Registered in England and Wales Registered Number: 1072954 Registered office:

Mortimer House, 37-41 Mortimer Street, London W1T 3J H, UK

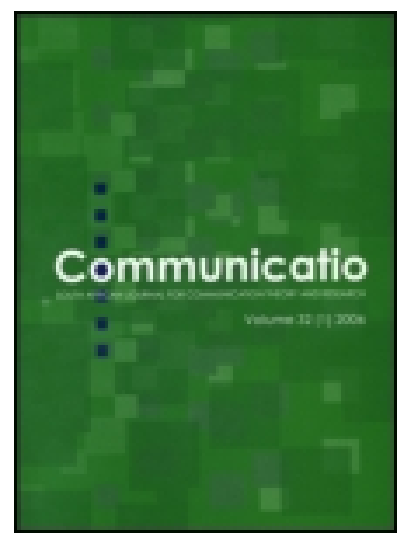

\title{
Communicatio
}

Publication details, including instructions for authors and subscription information:

http:// www. tandfonline.com/loi/ rcsa20

\section{International communication: shifting paradigms, theories and foci of interest}

Lucky Madikiza \& Elirea Bornman

Available online: 13 Aug 2008

To cite this article: Lucky Madikiza \& Elirea Bornman (2007): International communication: shifting paradigms, theories and foci of interest, Communicatio, 33:2, 11-44

To link to this article: http:// dx. doi.org/ 10.1080/02500160701685391

\section{PLEASE SCROLL DOWN FOR ARTICLE}

Full terms and conditions of use: http://www.tandfonline.com/page/terms-and-conditions

This article may be used for research, teaching, and private study purposes. Any substantial or systematic reproduction, redistribution, reselling, loan, sub-licensing, systematic supply, or distribution in any form to anyone is expressly forbidden.

The publisher does not give any warranty express or implied or make any representation that the contents will be complete or accurate or up to date. The accuracy of any instructions, formulae, and drug doses should be independently verified with primary sources. The publisher shall not be liable for any loss, actions, claims, proceedings, demand, or costs or damages whatsoever or howsoever caused arising directly or indirectly in connection with or arising out of the use of this material. 


\title{
International communication: shifting paradigms, theories and foci of interest
}

\author{
Lucky Madikiza \& Elirea Bornman*
}

\begin{abstract}
This article aims to be a stock-taking exercise of the development of paradigms and foci of interest, in attempts to theorise the vast developments and far-reaching changes as well as the impact and effects of global communication in the world of today. Attention is firstly given to the current nature, impact and implications of global communication in the first decade of the $21^{\text {st }}$ century, as well as to a shift in emphases in the (sub)discipline of international communication. A critical overview is then given of discourses on the free flow of information, modernisation theory, dependency theory, the structural theory of imperialism, world system theory, hegemony, political economy, critical theory, the public sphere, cultural studies, the information society and globalisation. Since many of these paradigms have been borrowed or taken over from media studies, international relations or other (sub)disciplines, attention is given specifically to their application in theorising international communication. The article concludes with a critical overview of the current 'state of the art' with regard to the body of theory in international communication.
\end{abstract}

Keywords: international relations, international communication, free flow of information, modernisation theory, imperialism, information society, globalisation

\section{INTRODUCTION}

In an age of satellite telephones, global CNN and the possibility of wireless Internet connection almost anywhere, it is hard to imagine that there exists a spot on earth that has not been touched by global communication (Stevenson 1992). However, global communication in the current world order is an amorphous and vast phenomenon with a tumultuous history, and manifold and far-reaching effects on macro, meso and micro levels (Mowlana 1996; Tehranian n.d.; Thussu 2000).

It seems an opportune moment, at the beginning of a new millennium, to reflect not only on the development and current state of global communication, but also on international communication as a field of study within the discipline of communication science. We not only aim to provide a brief overview of recent developments and trends in global communication, but also to reflect on attempts to theorise both the processes involved as well as the impact of the vast developments and wide-ranging changes that characterise global communication in our age. In this sense the article aims to represent a kind of critical stock-taking exercise of the shifting theories, paradigms and foci of interest in international communication. We hope that this discussion will whet the reader's appetite

Lucky Madikiza is a master's student in International Communication, Department of Communication Science, University of South Africa. E-mail:LuckyM@dbsa.org. Elirea Bornman is associate professor in the same department. E-mail: bornme@unisa.ac.za 
for more in-depth discourses on important issues in international communication in which we hope to participate in follow-up articles.

\section{GLOBAL COMMUNICATION IN THE WORLD OF TODAY}

International communication as a phenomenon is probably as old as human society itself and has occurred ever since people organised themselves into communities and began to exchange ideas and products (Mowlana 1996; Schoonraad, Bornman \& Lesame 2001). However, the phenomenon of global communication as we know it today is essentially the result of technological advances. It probably started with the development of advanced transport technology such as the steam engine and the internal combustion engine (Frederick 1993). Currently it is primarily driven by the worldwide proliferation of advanced information and communication technologies (ICTs).

The developments that gave rise to global communication as we know it in the first decade of the $21^{\text {st }}$ century started to evolve in the period between the two world wars (Mowlana 1996). During this period global connectedness was enhanced by the development of ICTs such as the telegraph and telephone; the laying of submarine cables between Europe and the USA; the expansion of railroads and the development of modern navigation with the help of newly developed radio technology. Global communication was further promoted by the commercialisation of the radio in the USA and the development and growth of the film industry. This period also saw the growth of major international news agencies in Europe and the United States, as well as the establishment, integration and transnationalisation of global institutions such as the International Telecommunication Union, the Universal Postal Union and the League of Nations.

The period was further characterised by the hegemony of the great European powers that used the developing communication technologies, media and international news agencies not only to enhance their powers globally and to acquire colonies and manage empires, but also to foster Westernisation and Europeanisation around the world. Growing industrialisation as well as the newly developed 'modern' institutions associated with the press, media and communication technologies furthermore contributed to the spread of ideologies associated with Westernisation, modernisation and secularisation in numerous Africa, Asian, Latin American and Arab societies.

The great world powers also started to realise the impact and importance of public opinion and the value of propaganda (especially in times of war) as well as the potential of the developing media (such as the radio) in this regard. The spread of contending ideologies such as liberalism, communism, fascism and a number of Islamic movements furthermore led to the increasing use of fast-developing media, press and communication technologies to organise the transnational activities of revolutionary movements. 
However, it was in the period after World War II that the growth in global communication really accelerated (ibid). This acceleration was mainly driven by the continued development and expansion of media such as television and, most importantly, the rapid development, improvement and widespread proliferation of ICTs such as satellites, computers and Integrated Services Digital Networks (ISDN). The global expansion of entertainment media as an import-export industry and the concomitant issues of copyright, intellectual property rights and privacy contributed to the spread of Westernisation. The rise and increasing internationalisation and integration of multinational institutions associated with the production and distribution of information as well as the creation of international communications organisations such as the International Telecommunications Satellite Consortium (INTELSAT) and International Maritime Satellite Organization (INMARSAT) further contributed to the growth in international information flows.

The rise of democracy and the attainment of independence by many former colonies of the great European powers also led to an increase in the number of nation states which participated in the political, cultural and socioeconomic aspects of international communication (ibid). During this period the USA emerged as the dominant political power and increasingly employed the media, as well as ICTs, not only for purposes of economic and military domination, but also culturally. Of particular importance was the Cold War period that once again served to emphasise the importance of international political communication such as propaganda. International political and cultural organisations such as the United Nations (UN) and the United Nations Educational Scientific and Cultural Organisation (UNESCO) further contributed to international debates on communication issues, while revolutionary movements around the world mobilised global communication networks to achieve their goals.

Whereas international communication was mainly an East-West issue in the period immediately following World War II, by the 1960s shifts in global power structures - characterised by the growing roles of the newly independent states within Africa and Asia - had brought the Third World to the forefront of debates on international communication (Ayish 2001). Global communication was initially perceived as a vehicle for establishing social change and economic growth - 'modernisation' in other words - in the so-called less industrialised and developing countries of the world (Mowlana 1996; Mowlana \& Wilson 1990). Driven by their frustration with decades of Western-oriented development models, Third World nations began to see the Western dominance of international economic and communication systems as causing their 'underdevelopment'. These frustrations resulted in calls for a New World Information and Communication Order (NWICO) and the establishment of the MacBride Commission as well as the entry of international organisations such as UNESCO into discourses on international communication. 
The acceleration of international conferences; the international expansion of educational institutions, congresses and seminars; the exchange of students between countries; the popularisation of international travel and the expansion of international sport further increased contact and communication between the peoples of the world (Mowlana 1996).

If global communication grew exponentially in the period after World War II, this growth accelerated even more in the period after the Cold War (Ayish 2001). The widespread diffusion of new technological innovations was incited by the increasingly liberalised free-market-oriented international environment of the post-Cold War order, where the borders between East and West had withered away. In this competitive world with its revolving economic and communication giants, the globe has since been transformed into a global electronic village and information has emerged as a primary commodity and resource.

The conclusion can be drawn that global communication is in a continuous state of ferment and evolution (Mowlana 1996; Tehranian n.d.). It not only takes a prominent place in virtually all aspects of contemporary global, national and local systems, but has also introduced to the world formerly unknown contradictions and uncertainties, some of which will be pointed out in the next section.

\section{SOME CONSEQUENCES AND EFFECTS OF GLOBAL COMMUNICATION ON THE CURRENT WORLD ORDER}

The effects of developments on global communication as we know it at the start of the $21^{\text {st }}$ century are manifold, diverse, wide-ranging and far reaching (Tehranian n.d.).

Economically, emerging communication networks have played a major role in the increasing internationalisation and liberalisation of economic activities (Bornman \& Schoonraad 2001). Due to the rapid development of ICTs, geographical boundaries and temporal disparities no longer form barriers to international trade, capital flow and other economic activities. A global trans-border or virtual market has emerged. Global communication networks are furthermore enabling transnational corporations (TNCs) to conduct their activities in virtually every corner of the world. Transactions within the emerging global market have also become increasingly dependent on international information flows facilitated by modern ICTs. Thus, as already mentioned, information has become a paramount commodity and access to information - and consequently also to modern ICTs - plays a major role in economic advancement and growth.

Politically, global communications are not only challenging the legitimacy, sovereignty and authority of the nation state, but also have far-reaching implications for international 
relations (Bornman 2003; Bornman \& Schoonraad 2001; Tehranian n.d.). The borders of nation states have become porous as the globalisation of technology has made it virtually impossible for governments to regulate and control the trans-border flow of information and communication. In this way global communication is increasingly undermining the authority and legitimacy of nation states. Global communication is also empowering marginalised and often forgotten groups and voices in the international community, which furthermore presents a challenge to the authority of the nation states within whose boundaries they live. The many interactive forms of global communication have also created immense new moral spaces for exploring new and/or alternative communities of affinity and identity. Vicinity - often presented by the nation state or region where an individual or group lives - is consequently no longer the only viable context for identity formation.

Global communication is furthermore increasingly changing the rules of international relations (Tehranian n.d.). Firstly, modern ICTs are facilitating the transfer of science, technology, information and ideas from the centres to the peripheries of power. Foreign relations through diplomacy have been enhanced as well as undermined by global communication. The emergence of a global civil society, presented by a multitude of non-state actors and non-governmental organisations (NGOs) together with intergovernmental organisations (IGOs), TNCs and transnational media corporations (TMCs), are increasingly complicating the context of international relations and diplomacy. TNCs are furthermore changing economic infrastructures, trade relations as well as internal and political relationships which has implications for national security, the conduct and deterrence of war, intelligence collection, analyses and dissemination as well as for the conduct and deterrence of terrorism. A further complicating factor is the resurgence and revitalisation of ethnicity that has resulted in the emergence of international politics of identity and difference related to religious, ethnic and/or racial fetishisms. Global media systems have introduced propaganda and public diplomacy as important factors in international relations. Thus global communication is radically redefining the nature of both hard and soft power in international relations.

Socially integrated global communication networks have, to a certain extent, resulted in the realisation of McLuhan's (1964) notion of the 'global village' with the emergence of, among others, global interconnectedness, global consciousness and global cooperation between NGOs in widely different areas such as human rights, women's rights and environmental protection. Social relations are no longer restricted to a particular space or locality, but are dispersed globally and spatially as ICTs create and maintain social relations irrespective of time and space.

Culturally, emerging patterns of global communication are creating a new global 'CocaColanised' consumer culture of 'commodity fetishism' that is supported by the global advertising and entertainment industries (Tehranian n.d., par 2). In its human dimension, 
the altered social, political and economic environment has led to increased interaction with and confrontation between one culture and another (Mowlana 1996). In doing so, international communication is changing the nature and problems associated with intercultural communication.

However, one of the most important consequences is probably the blurring of the boundaries between the technological, economic, political, social and cultural domains (Tehranian n.d.). Both traditional media (such as print, photography, film, radio, television and video) as well as the fast-developing new information and communication technologies (ICTs such as telephone and telegraphy, satellites and computers) which initially developed fairly independently, are now merging into a global digital telecommunications network. Within the economic sector, the separate industries associated with each of these technologies are also combining through a series of corporate mergers and alliances to serve the new multimedia environment. Overall, global communication is one of the major factors encouraging globalism and its discontents such as supranationalism, nationalism, regionalism and fundamentalism, but it also plays a major role in mobilising resistance against globalism.

\section{REVISITING THE TERM 'INTERNATIONAL' IN INTERNATIONAL COMMUNICATION}

Within this tumultuous and continuously changing landscape of global communication, the (sub)discipline of communication science, dedicated to the phenomena related to global communication, is commonly known as 'international communication'. However, from previous discussions it should be clear that the term 'international' no longer reflects the full scope of global communication as we currently know it. Prominent authors in the field, such as Mowlana (1996, 1997) and Thussu (2000), consequently raise the question of whether the term is still appropriate.

The Collins English Dictionary (2006: 417) defines the term 'international' as '1.) of or involving two or more nations; 2.) controlling or legislating for several nations'. Thus the classic understanding of 'international' refers to that which exists, involves or is carried across or takes place between two or more nation states. According to this definition, the field of international communication should be understood to focus mainly on interactions between and among nation states. International communication as a field of study has indeed developed from the study of international relations (Mowlana 1996, 1997). Thus analyses of international communication have traditionally been associated with inter-state and inter-governmental interactions such as diplomacy and government propaganda, in which powerful states dictate the communication agenda (ibid).

However, vast developments in the media and ICTs during the late $20^{\text {th }}$ century have resulted in a radical expansion of the scope of international communication. Currently 
communication across national borders has expanded to a large diversity of businessto-business and people-to-people interactions on a global level. Furthermore, not only the representatives of nation states, but also a variety of non-state actors such as international non-governmental bodies, social movements as well as ordinary individuals are increasingly shaping the nature of transnational communication (Mowlana 1996).

Mowlana (1997) consequently proposes a shift from the classical view of international communication to a vision of global communication in order to reflect the full scope of communication between nation states, institutions, groups and individuals across national, geographical and cultural borders. The term 'global communication' is also reflected in the titles of books such as Global communication in the $21^{\text {st }}$ century (Stevenson 1994) and Global communication and world politics (Tehranian 1999). Hamelink (1994: 2) prefers to employ the term 'world communication', as it is more inclusive of both state and non-state actors.

In accordance with the expanding scope of international communication, Thussu (2000: 1) defines international communication simply as communication that occurs across international borders. According to the Massachusetts Institute's Center for International Studies (MIT center), words, acts or attitudes can be defined as international communication whenever they impinge - intentionally or unintentionally - upon the minds of private individuals, officials or groups from other countries (in Mowlana 1996: 9). These definitions not only broaden the scope of international communication beyond the ambit of inter-statal and inter-governmental communication, but also deviate from a mere technological focus by acknowledging the human and social dimensions of global communication within a complex process of manifold interchanges by means of signs and symbols. Thanks to these definitions, international communication is depicted as an extremely broad field involving social conditions, attitudes and institutions that have an effect on the production and/or reception of various forms of communication among people. Thus, international communication as a field of study recognises not only the media and technologies through which impulses pass, but also the attitudes and social circumstances of the sources, the predisposition of receivers, as well as the effects and impact of the contents.

Although we fully acknowledge the expanding scope of the field, we will continue to use the term 'international' when referring to the field of study - not only because the field and related phenomena are more commonly known by this term. However, we use the terms 'global communication' and 'world communication' interchangeably with 'international communication' when referring to the multitude of processes and phenomena related to the field. 


\section{THEORISING INTERNATIONAL COMMUNICATION}

There can be little doubt that a body of theory with testable propositions is essential not only to conceptualise and explain the multiple phenomena associated with global communication (Mowlana 1996; Stevenson 1992). In practice, international communication has borrowed and/or adapted theories and paradigms from (sub)disciplines such as international relations and media studies and applies these to discourses related to global communication. The following sections give a critical overview of the shifting theoretical frameworks, paradigms and foci of interest:

\section{The free flow of information}

Discourses on the notion of the 'free flow of information' emerged during the Cold War when the international community was characterised by the bipolar division between capitalism and socialism (Ayish 2001; Thussu 2000, 2005). In initial debates on international communication, the free-flow principle was associated with, on the one hand, the antipathy of Western liberalism and capitalism to state regulation and censorship of the media, and their demands for an unrestrained flow of information (including - according to Thussu (2000) - Western propaganda). Marxists, on the other hand, argued for greater state regulation to control the flow of news and broadcasting materials into their societies.

The free-flow discourse is deeply embedded in discourses on democracy (Ayish 2001). In a democracy, the role of the mass media is believed to be to inform the electorate on public issues, to enlarge the base of participation in the political process and to watch over government behaviour. Proponents of a free flow of information base their arguments on the liberal discourse of the rights of individuals to freedom of opinion and expression. Systems of freedom of expression and information are regarded as central tenets of democracy and preconditions for the media to promote democracy. Debates on the freedom of information during the Cold War consequently focused largely on the international flow of news and broadcast materials.

During the 1940s and 1950s the principles of the 'free marketplace of ideas' and the 'free flow of information' not only became central components of US foreign policy, but were also endorsed in the United Nations Charter, the Universal Declaration on Human Rights and other related UNESCO declarations. However, whereas free-flow debates were predominantly an East-West issue in the period immediately following World War II, the 1960s saw a change in global power structures as the newly independent African and Asian nation states entered debates on international communication (ibid).

Third World countries came to believe that Western dominance of their economic and communication systems was to blame for their 'underdevelopment'. They proposed 
that international information systems perpetuated existing inequalities and the dependence of the Third World on the developed North for both hardware and software in the communication sector (Ayish 2001; Thussu 2005). Imbalances in the flow of communication and information were furthermore believed to pose threats to their political independence and national sovereignty, cultural values and socioeconomic development. These allegations were supported by empirical data that indicated that communication with the Third World was indeed a one-way flow from the developed centres - unbalanced and distorted, it tended to focus on 'negative' instead of 'development' news. In his call for a New World Information and Communication Order (NWICO), Masmoudi (1979) comments in this regard that the principle of freedom to information became the freedom of the informing agent, and as such an instrument of domination in the hands of those who control the media.

Scholars also note that the West - the United States in particular - has indeed benefited from notions such as 'the free marketplace of ideas' and 'the free flow of information', and that these concepts evolved internationally in conjunction with global American and Western economic expansion and served to justify this expansion (Ayish 2001; Thussu 2000, 2005). As the bulk of the world's media resources were concentrated in the West, the governments of Western countries and Western private enterprise had most to gain from an absence of restrictions to communication flow. Media and communicationrelated organisations used the free-flow principle to argue against trade barriers to the international distribution of their products and services, as well as against attempts to hinder news gathering within the territories of other countries. Western businesses, in turn, have been benefiting from the concomitant advertising and marketing of their products and services in foreign markets. The Western information and entertainment industries have furthermore served to champion the Western way of life as well as the values of capitalism and liberalism on the international stage. Thus the free-flow principle not only helped strengthen and consolidate the influence of the West in its ideological battle with the Soviet Union during the Cold War. In general, it has served to spread the Western doctrine - in particular that of the United States - to the international community and also to Third World countries.

In campaigning for greater equality and balance in news and communication flows, Third World nations' calls for a New World Information and Communication Order (NWICO) resulted in the Brandt and MacBride Commissions and their respective reports (Ayish 2001, 2005; Preston 2005; Thussu 2005). The MacBride report in particular, entitled Many voices, one world, published in October 1980 by UNESCO's International Commission for the Study of Communication Problems, generated wide-ranging debates on transnational media flows; norms and ethics within the communication professions; the role of communication technologies; and the social, cultural and democratic impact of the media. The most far-reaching of the 82 recommendations of the report dealt with the democratisation of communication. The Commission acknowledged that the 
democratisation of communication is hindered by undemocratic systems of governance (involving, among others, excessive bureaucracy) as well as by a lack of appropriate technologies and illiteracy. In order to create a more balanced and equal international communication environment, the Commission proposed the participation of the public and their representatives in media management as well as the fostering of horizontal communication and counter information. It also propagated three forms of alternative communication: radical opposition, local or community media movements, as well as trade unions. It furthermore coupled press freedom and the right to self-expression with the rights to communicate and receive information, the rights to reply and make correction, as well as the social and cultural rights of communities. A central theme of the report - as reflected in the title - is that the media should serve social and cultural development and contribute to cultural and social understanding. Thus the notion of diversity is emphasised as a prerequisite for a more balanced and culturally fulfilling international communication environment. However, the report points out that, in order to promote dialogue between equals in which all nations and people participate, opportunities and resources should be spread more equally.

Whilst the MacBride report was hailed by Third World nations as the first document to bring world communication problems to the fore, it was denounced by Western-based media institutions for its criticism of private media and communication ownership, and the social problems that result from advertising. Western nations, led by the USA, perceived the NWICO as an attempt to propagate state regulation of the media - a notion perceived to be in conflict with liberal Western values and the principle of the free flow of information. The NWICO was furthermore blamed for curtailing media freedom and the freedom of speech while promoting the reinforcement of authoritarian political censorship. In essence, Western opposition to the NWICO reflected a need to ensure that government-controlled public media would not be promoted at the expense of the private media sector. The USA demonstrated its opposition by withdrawing its aid from the UNESCO-supported International Programme for the Development of Communication (IPDC) culminating, finally, in its withdrawal from UNESCO itself - a move followed by the United Kingdom a year later.

Thussu (2005) points to the fact that the emphasis on the primacy of the private sector reflects a deeper ideological shift emanating from the US and other Western governments at the time. It represents a shift away from the public service-oriented view of media and communication to an emphasis on a privatised and deregulated industry. The free-market doctrine was fuelled by the end of the Cold War, which fundamentally transformed the bipolar world that had dominated free flow debates for decades into a unipolar universe dominated by the world's only remaining superpower. This superpower, the USA, deployed all its power and influence to champion market solutions for the world's communication problems. Privatisation became the new mantra and resulted in the deregulation, privatisation and liberalisation of the broadcasting and telecommunications sectors. 
Although debates on the NWICO have become rather quiescent in recent years, Ayish (2001) holds that the free flow of information remains a controversial issue in international communication. Currently discourses are influenced by two important global trends, namely the worldwide proliferation of newly developing ICTs and the worldwide democratisation of political systems in the aftermath of the demise of the Soviet Union - a traditional supporter of the NWICO. The technodemocratic revolution brought about by these developments has lowered the significance and validity of the ideological underpinnings of the debate, in favour of focusing attention on information as a central component of the world economy. Terms such as 'informatics' and 'telematics' have been developed to indicate the importance of the emerging global order, in which information plays a central role. The shift in emphasis from the mass media to information furthermore signifies the rising importance of economic aspects of communication at the expense of cultural and political aspects.

The demise of the Soviet Union, the shift from state-regulated to market-oriented policies, as well as the establishment of transnational institutions such as the World Trade Union (WTO) and the International Telecommunication Union (ITU) have furthermore created a global market for information and communication. A strong communication infrastructure has become a prerequisite for participation in the global economy, while the dismantling of barriers to the free flow of information is perceived to be essential for economic growth and development. Thus the free-flow doctrine has been extended to include both the contents of communication as well as the infrastructure that enables the flow of communication and information.

In terms of these developments, conceptions of information solely in terms of news and broadcasting have become archaic (Ayish 2001). However, the question of the proliferation of technologies has been introduced at NWICO and other debates on international communication since the 1960s (ibid). Third World nations have been concerned that, if news and broadcasting materials could have far-reaching effects on their societies, the effects of powerful communication satellites, trans-border data flows and digitalised and interactive computer-related communication could be even more serious for their national sovereignty and indigenous cultures.

Even more importantly, existing imbalances and widening gaps in the proliferation of new ICTs between them and Western developed countries could hinder social and economic development in Third World countries (ibid). Most scholars agree that it is quite misleading to speak about a free flow of information and the participation of Third World countries in international communication in light of current imbalances in telecommunications infrastructures. The governments of Third World countries consequently have not only called for policies to guard against the uncritical transfer of technologies and the potential negative effects of the international flow of information, but also against the potentially adverse effects of imbalances in the spread of ICT infrastructure. 
However, in accordance with its general approach to the free flow of information, the West still supports a liberalised, free-market approach to the proliferation of ICTs (ibid). This viewpoint is currently largely based on the notion of 'market technicalism' which views market competition as the engine for the development and proliferation of ICTs that will be conducive to the free flow of information and wider participation in democratic processes and will, ultimately, also redress inequality in information flows.

Ayish (2001) points at another shift in debates on the free flow of information. The breaking tide of democratisation in the Third World has forced governments of developing countries to revisit their radically negative views on the free flow of information. This is particularly true in the post-Cold War order, where the political weight of Third World countries has decreased and they have been forced into political realism in order to ensure that their perspectives keep the attention focused on the international agenda. Although Western notions of the free flow of information - and a free press in particular - are still criticised as being over-liberal, self-centred and anti-state, Third World governments have become more willing to tone down their opposition to the free flow principle in return for greater Western appreciation for their employment of mass media for development purposes. Challenges to the liberal conceptions of free flow are consequently no longer based on authoritarian and Marxist ideologies, but rather on perspectives of social responsibility. This rather libertarian idea, based on the emphasis of social needs and social responsibility, serves to justify certain restrictions to the free flow of information. It has also shifted international debates from the radical 'free versus controlled' dichotomy to 'responsible versus unrestrained' perspectives on the free flow of information.

Ayish (ibid) draws the conclusion that the changing nature of discourses on the free flow of information reflects the changing nature of global politics and the global economy. It serves to illustrate the close relationship between international relations and global communication.

\section{Modernisation theory}

Complementary to discourses on the benefits of the free flow of information in the years after World War II were views on the key role of international communication in the process of modernising and developing the Third World (Thussu 2000).

The modernisation theory emerged during a period when it was very important for the West to bring the newly independent nations of Asia, the Middle East and Africa into the sphere of capitalism (Ayish 2005; Thussu 2000). The paradigm is founded on the notion that international mass communication should become the vehicle for spreading the message of modernity, transferring Western economic and political models and transforming and modernising traditional societies. Modernisation (or 'development 
theory' as this pro-media bias is called) has been highly influential. Research based on the paradigm has not only served to shape university communication programmes and research centres, but has also been generously supported by UNESCO and other international organisations.

The modernisation paradigm is based on the premise that as nations emerge from colonialism, there would be a natural development of the previously colonised countries along the same route or stages followed by Western countries (Thussu 2000). The developed Western societies consequently served as models for the less developed societies to strive for. It was widely accepted that the mass media would serve as a bridge to a wider world and would be instrumental in spreading education, transferring essential skills, fostering social unity, and - most importantly - creating the desire to 'modernise'. This top-down, one-way approach to communication via the mass media was regarded as a panacea for the transformation of the Third World. The level of media development of a country consequently served as an indicator of general societal development. One of the earliest exponents of the theory was Daniel Lerner (1958) who believed that the mass media could break the hold of traditional cultures on societies and make them aspire to a modern way of life. Similar viewpoints were held by other important modernisation theorists such as Wilbur Schramm (1964) and Everett Rogers (1962) with his 'diffusion of innovations' theory.

Major shortcomings in the modernisation theory have been pointed out (Thussu 2000). First, measuring a country's level of development according to its Gross National Product (GNP) fails to recognise that the creation of wealth on its own is not sufficient and that the welfare of a population at large depends also on the equitable distribution of wealth and its use for the public good. It thus happened that social and economic disparities widened in many Third World countries, despite them showing signs of economic growth. The modernisation theory furthermore neglects to take the political, social or cultural dimensions of development into account and fails to ask questions such as: Development for whom? and Who would gain? The consequence was that in many Third World countries economic and political power remained restricted to small elites, and the media served to legitimise their power.

The media were also regarded as a neutral force, thus ignoring the fact that all media products are shaped by social, cultural, political and economic factors. Questions regarding whether the audience could receive the message (television penetration in developing countries was, for instance, minimal), understand it and whether they might respond by showing some form of resistance, were also neglected. Another major shortcoming is the dismissive view regarding traditional cultures and the assumption that modern and traditional lifestyles are mutually exclusive (ibid). Thus developing countries criticised the theory for its ethnocentric Western orientation, ahistoricity (failure to take the history and culture of local communities into account), linearity 
(holding a simple linear view of development) and for advancing solutions that, in reality, reinforce the dependency of the Third World on developed countries (Ayish 2005).

Since modernisation programmes did little to alleviate the plight of the poor in the Third World, critics increasingly started to question the validity of the premises of the paradigm and focused on issues which they felt had been left out, namely the relationship between communication, power and knowledge, and the ideological role of international organisations and institutional structures (Thussu 2000). Prominent in this regard was the work of Latin American scholars such as Paolo Freire with his Pedagogy of the oppressed (1974). Western scholars also began to recognise that the modernisation paradigm needed to be reviewed. Alternative paradigms, such as that of participatory development, have since emerged.

However, in a revised version of the modernisation paradigm, blind faith in the mass media has been replaced by similar beliefs in the potential of ICTs to help developing countries 'leapfrog' stages of development. Within this model, the dissemination of information is often perceived to be the panacea to foster development (Castells 1998; Thussu 2000). According to Nulens and Van Audenhove (1998) this idealistic approach - also known as the technophilic view - assumes that ICTs have largely positive effects on society, such as an increase in job opportunities, increased efficiency in both private and public sectors, social harmony and the deepening of democracy. However, critics of this view - the so-called technophobes - point to the fact that ICTs could also hold serious negative effects for developing countries (Van Dijk 1999; Mansell \& Wehn 1998).

Whereas the discourse on the assumed benefits of ICTs is continuing, increasing frustration among developing countries gave rise to critical paradigms regarding the role of international communication in national development.

\section{Dependency theory}

The dependency paradigm emerged as the most prominent theoretical framework questioning the modernisation paradigm (Ayish 2005). The dependency theory had its origins in Latin America during the 1960s and 1970s, during a period when countries of the Third World realised that the developmental approach to international communication had failed to deliver (Thussu 2000). Although it is rooted in the neo-Marxist political economy approach (see page 30), the dependency perspective represents an important shift away from the nation state as unit of analysis, to a predominantly international level of analysis (Servaes, Jacobson \& White 1996). Thus it emphasises global structures and interrelationships that influence Third World development and postulates that post- 
independence dynamics keep Third World countries locked in former colonial power structures (Ayish 2005).

For the dependistas, the world should be analysed in terms of a 'centre' - comprising mainly Western countries such as the USA and Western Europe - and the 'periphery' which encompasses the poor countries of the world, such as those from Africa who have recently emerged from colonialism, but remain 'dependent' in various ways on the rich Western countries. The lack of development of the periphery is ascribed to historical and current forms of colonialism and exploitation through institutions and companies - especially transnational companies (TNCs) - in the centre. TNCs, with the support of their respective governments, are believed to exercise control over developing countries by determining the terms of global trade and the structure of global markets. Development is conducted in such a way that it strengthens dominance over countries on the periphery and maintains them in a position of dependence. Such development attempts are typified as 'dependent development' or 'the development of underdevelopment' (Frank in Thussu 2000: 61). In contrast, 'true' development is conceived as an autonomous, self-chosen path drawing from indigenous cultures (Ayish 2005).

The dependistas argue that the domination of the periphery by the centre occurs through a combination of power components, for example through the military, economics, politics and culture (Servaes, Jacobson \& White 1996: 34). Countries on the periphery, for example, come to depend on Western-developed technology and investment and the demand for media products - television programmes in particular - necessitates large imports from centre countries. These imports serve to promote, albeit indirectly, the Western-American lifestyle as well as Western goods and products. The result is a socalled electronic invasion that threatens the cultures of countries on the periphery and promotes a consumer lifestyle at the expense of community values. The term 'cultural imperialism' is used in this regard to argue that international media flows of both media hardware and software serve to strengthen dependency and hinder true development (Ayish 2005). Closely related to cultural imperialism is the concept of 'media imperialism' which emphasises more specifically media inequalities between the centre and the periphery, and how these inequalities reflect broader issues of dependency, exploitation and hegemony especially with regard to Western-dominated international media such as news agencies, magazines, films, radio and television (Boyd-Barrett 1977). Also related is the concept of 'electronic colonialism' that refers to inequalities in ICT infrastructure and hardware and the role of MNCs in this regard (McPhail 1981).

There are, however, also many critics of the dependency theory (Thussu 2000) who point out that it lacks clear definitions of key terms such as 'imperialism' and has failed to present empirical evidence to support the main arguments of the theory. It is also criticised by cultural theorists in particular for neglecting the form and contents of the 
media and the role of the audience. Media audiences are perceived to be passive receivers of media contents - a type of 'hypodermic needle' approach. Cultural theory, in contrast, assumes that media texts are mostly polysemic in nature and could be interpreted in various ways by audiences who are not passive consumers, but active participants in negotiating meaning. The cultural imperialism thesis is furthermore criticised for being totalitarian for not taking into account how the meaning of global media contexts is negotiated in various national and local contexts, and for ignoring local patterns of media consumption.

Despite its shortcomings, the dependency perspective is nevertheless important as it heralded the beginning of a critical tradition in international communication. Prior to its advent, theorising and research largely focused on the preservation and promotion of the objectives of powerful nation states, thus supporting the status quo. The dependistas also played a prominent role in the NWICO as well as in the Non-Aligned Movement, which made their impact felt in international fora (Servaes, Jacobson \& White 1996).

With the shift from discourses in international communication to issues of privatisation and liberalisation in the 1990s, theories of media and cultural dependency have moved to the background. However, Boyd-Barrett (in Thussu 2000: 64) declares that the concept of imperialism remains a useful tool to analyse the so-called 'colonisation' of communication space. The notion of cultural imperialism has, indeed, moved to the forefront again in discourses on cultural globalisation - one of the latest paradigms of theory and research (see page 37).

\section{Structural theory of imperialism}

Galtung's (1971) structural theory of imperialism can be regarded as an expansion and refinement of the dependency theory. It not only offers explanations for existing inequalities between regions, nation states and collectivities, but also emphasises the possibility of the existence of inequalities within a particular region, nation state and/or collectivity. Galtung points to the fact that there are elites in peripheral countries whose interests coincide with those of elites in the centre. These 'cores' or 'centres' within peripheral states provide a bridgehead through which the centre can enact its dominance of the periphery. In terms of culture, values and attitudes, elites in the periphery are often nearer to elites in the centre than to the people in their own country (Thussu 2000).

Galtung (1971) attempts to define the concept of 'imperialism' more precisely by distinguishing between interaction relationships and interaction structures that result in imperialism. He holds the reason for interaction between nation states or collectivities as the fact that they dispose of different complementary resources which creates the need for exchange. For example, one nation state could have the resources essential 
for the production of a particular product, while another might have the factories and skills to produce the product. Both parties are changed when resources are exchanged. In an imperialistic relationship, a gap is created and/or widened when the exchange is cumulatively unequal or asymmetric as regards the benefits for each party. The factors which determine whether exchanges are equal or unequal are the nature of the value exchange between the two parties, as well as the positive or negative consequences for each.

Imperialistic interaction structures are characterised by vertical and feudal forms of interaction (Galtung 1971; Thussu 2000). The principle of vertical interaction maintains that relationships are asymmetrical and that the flow of power is vertical from the centre to the periphery. Feudal interaction implies that interaction is monopolised by the centre and follows the spokes of a wheel, that is from the periphery to the centre and vice versa, while there is little or no interaction along the rim, in other words between peripheries. The result is that peripheries become dependent on the centre(s).

Galtung (1971) distinguishes five forms of imperialism, depending on the nature of exchange relationships: economic, political, military, communication and cultural. Together these forms of imperialism constitute a syndrome of imperialism and reinforce (through various channels) the dominance of the centre over the periphery. Communication imperialism is, among others, related to media imperialism, disparities in the flow of news as well as inequalities in access to ICT infrastructure which ultimately results in cultural imperialism. Information flows from the centre to the periphery and back again. For example, regions, nation states and collectivities in the Third World receive news from the Northern countries via transnational news agencies, but little information from other countries in the Third World. Third World societies consequently have little information about neighbouring countries that has not been filtered through the media systems of the North (Thussu 2000).

Galtung's (1971) theory of cultural imperialism bears a stark similarity to cultural imperialism - as distinguished in dependency theory - as both hold that the political and economic dominance of the centre over the periphery changes the value systems of societies on the periphery (Thussu 2000). Research on media and information flows also confirms a dependency relationship between the centre and the periphery, that is a predominantly one-way flow of information, values, ideas, methods, skills and resources from the North to the South.

Both imperialism and dependency theory are being criticised for focusing mainly on the role of external forces in the social and economic development of countries on the periphery, while neglecting the role of internal class, gender, ethnic and power relations (Thussu 2000). Galtung responded to this criticism by doing research on the elites of peripheral countries and found that they, indeed, benefited from the dependency 
syndrome. However; although the worldwide proliferation of ICTs and the emphasis on cultural hybridisation (rather than imperialism) have made theories of imperialism less fashionable, Thussu notes that the structural inequalites in international communication deem the recognition of their continued relevance in discourses on dependency and imperialism within the field of international communication to be vital.

\section{World system theory}

World system theory is regarded as an expansion of dependency theory and imperialism theory (Chase-Dunn \& Hall 1993; Shannon 1996). However, one of the most important contributions of the theory is the fact that - instead of focusing predominantly on relationships between the centre and the periphery - it acknowledges the emergence of a new social system, namely a global or world system, in the current world order.

Wallerstein (in Chase-Dunn \& Hall 1993: 854) defines the world system as a multicultural network for the exchange of 'essential goods'. The term 'world system' indicates the social context in which people in the modern era live. However, not all interactions are necessarily of a global nature. The systemic character of the world system is rather situated in the fact that events in one part of the globe have important consequences for events, interactions and social structures in other parts of the world. It also indicates that - due to the worldwide proliferation of ICTs - various smaller systems are connected to form a global system.

The reference to multicultural networks indicates that the networks connect people, groups and societies that differ culturally, speak different languages and have different normative institutions. Chase-Dunn and Hall (1993) furthermore recommend that the definition not only focus on cultural groups organised in nation states, but also on smaller units such as cultural minorities, so-called 'stateless' groups as well as organisations and individuals. They consequently prefer the term 'composite units' to 'societies' or 'states'.

Whereas Wallerstein initially refers to essential goods purely in terms of food and raw materials necessary for the fulfilment of material needs, Chase-Dunn and Hall (1993) broaden this view by including all social and other forms of interaction worldwide that serve to uphold or change internal structures. It consequently also refers to forms of interaction such as wars, diplomacy, intermarriages, and - most importantly - the exchange of information. Thus economic, political, cultural and scientific forms of interaction all form part of the world system.

World system theorists also acknowledge inequality or hierarchy - as they prefer to call it - in the structure of interactions within the world system (Chase-Dunn \& Hall 1993; Shannon 1996). Shannon adds another level to the twofold distinction between centre 
and periphery. He defines a third zone - the semi-periphery - which refers to nation states and regions that can compete with the centre in certain aspects, but in other aspects resemble the periphery. Brazil and Argentina are mentioned as examples of states on the semi-periphery. The principle of hierarchy indicates political, economic and ideological dominance between composite units that is the consequence of political dominance, inequalities in exchange and interaction relationships and the exploitation of resources. However, world system theorists differ from dependency and imperialism theorists in that they do not necessarily assume that all relationships and forms of interaction between the centre and periphery are necessarily unequal, but also make provision for the existence of equal relationships between various levels. They furthermore point to the possibility that dominance can also exist between units on the same level. In order to account for inequality in a particular case, it is consequently necessary to analyse the complexity of relationships and interactions.

The fact that world system theory acknowledges both equal and unequal relationships makes it a useful theoretical framework for empirical research into the flow of capital, international relationships, media contents and information in the new global order. However, the theory can be criticised for the fact that it gives little attention to the causes and consequences of inequality, dominance and hierarchy in the world system.

\section{Hegemony}

Theorising regarding the process of hegemony has had a major influence on critical theorists as well as cultural critics (see pp. 31 and 35). The theory of hegemony is based on the work of the Italian Marxist, Antonio Gramsci (1891-1937), who died in prison under the Fascist regime in Italy (Thussu 2000).

In accordance with Marxist viewpoints, society is perceived as the site of struggle among interests through the domination of one ideology over others (Littlejohn \& Foss 2005). Hegemony refers to the process of domination where one set of ideas subverts, co-opts or dominates another. According to Gramsci (in Thussu 2000: 68), a dominant group in society has the capacity to exercise intellectual and moral control over society at large, with the support of a system of social alliances. Military force is not regarded as the only or most effective force to retain power. The building of consent by means of the ideological control of cultural production and distribution is a much more efficient instrument in wielding power. Such a system exists when a dominant class exerts moral and intellectual dominance over a subordinate class by means of institutions such as schools, government institutions, religious bodies and the mass media.

In international communication, the concept of hegemony is often employed to refer to the political, social and cultural functions of the media (Thussu 2000). The international mass media are regarded as key players in propagating and maintaining the ideologies 
of dominant forces within the global system. Even if and when the media are free from direct governmental control, they nevertheless act as agents to legitimise the dominant ideology. Gramsci's ideas on hegemony are also the foundation stones of political economy and critical theory, which are discussed in the following sections.

\section{Political economy}

Thussu (2000) regards the political economy approach as an umbrella theory that encompasses many of the other theories of international communication, such as dependency and hegemony. In contrast to cultural analyses (see p. 35), it primarily concerns itself with underlying structures of political and economic power.

Central to Marx's interpretation of international communication is the question of power which is perceived as an instrument the ruling classes use to control the masses (Thussu 2000). According to this view, the class with the means of material production simultaneously controls the means of mental production. In other words, the ruling class regulates both the production and distribution of the ideas of its age.

In international communication, much of the critical research with regard to political economy has been related to patterns of ownership and production in the media and communications industries (ibid). These have been analysed within the overall context of national and transnational social and economic power relations. One of the central themes of research has been the commodification of communication hardware and software and its impact on inequalities in access to the media and communication.

One of the important themes within the critical political economy approach in international communication is the transition from American post-war hegemony to a global order where world communication is dominated by transnational and multinational corporations supported by their national governments, which are linked to and integrated in global structures (ibid). Researchers mainly focus on corporate and state power, especially with regard to patterns of ownership in media and communication industries worldwide. In particular, attention is given to vertical integration (of companies controlling a specific sector) as well as horizontal integration (across sectors as well as companies within and outside media and communication industries).

Scholars such as Hamelink (1979, 1983, 1994) have been campaigning for information and communication equality and have introduced human rights issues to debates on international communication. Critics of the dominant market-based approach, on the other hand, have been advancing the public-service approach of state-regulated media and communications, where public interest concerns are given preference to governmental regulatory and policy bodies at national, regional and international levels (see Fourie 2003). 
In the $21^{\text {st }}$ century, Thussu (2000) and Preston (2005) have pleaded for a revival of research into the political economy of international communication if the (sub)discipline wants to claim relevance with regard to pressing social and political issues. In doing so, significant contributions can also be made to the wider scene, such as international relations in the world of today. Important themes for analysis are the role of transnational media and communication corporations, as well as international organisations such as the WTO and the ITU in the increasingly market-driven international environment. In this regard Thussu (2005) mentions the extensive control that Rupert Murdoch's News Corporation exercises globally, over both information hardware (such as delivery systems) and software (such as programme content). Another important topic is the influence new ICTs, such as the Internet, have on the international communication environment. These need to be studied against the background of the challenges presented by events in the global order, such as the demise of the Soviet Union, the introduction of market socialism in China and the rightward shift of the left in Europe and Third World nations. It can therefore be predicted that the critical political economy approach will remain an important paradigm within international communication research - it can play a vital role in our understanding of the expansion, acceleration and consolidation of global media and communication industries.

\section{Critical theory}

Critical theory is yet another theoretical tradition with its roots in Marxism. It holds that the means of production in society - that is the economic structures - determine the nature of society (Littlejohn \& Foss 2005). Researchers at the Institute for Social Research in Frankfurt - known as the Frankfurt School, with prominent researchers such as Max Horkheimer, Theodor Adorno and Herbert Marcuse - played a leading role in the development of the theory. With the rise of Nazism in Germany, the scholars of the Frankfurt School emigrated to the USA where they established the Institute for Social Research at Columbia University. Here they devoted their attention to the impact of the mass media and the international production of cultural goods (films, radio programmes, music and magazines) on societies.

Within the critical tradition, mass media structures are predominantly perceived as structures of oppression (Thussu 2000). It is argued that in capitalist societies culture is commodified, as cultural products have assumed an exchange value that has largely replaced their intrinsic value. Management practices, technological rationality and organisational structures similar to those involved in the production and exchange of commodities such as, for example, cars, are also employed in the production of cultural products. Cultural products are furthermore sold to consumers in the marketplace just as other commodities whose value is not determined by their intrinsic worth, but rather by their entertainment value and ability to satisfy psychological needs. This 'assembly-line 
character' of cultural production results in standardisation bearing an industrial stamp. The standardisation and commodification of culture is furthermore aggravated by the concentration of the ownership of production of cultural products in a few producers and countries of the world.

According to cultural theorists, the resultant mediated 'mass culture' that thrives on market rules of demand and supply, has various negative effects (ibid). It firstly leads to the deterioration of the philosophical role of culture. Furthermore, it undermines the ability of the masses to critically engage with important socio-political issues and leads to politically passive behaviour and the subordination of the masses to the ruling elite. It also serves to incorporate and immerse the working classes into the structures of capitalism, thus limiting their political and economic horizons as they no longer seek to challenge these structures.

Within international communication, critical theories have stimulated debate on the international flow of information (ibid). Issues regarding the commodification of culture have furthermore become central in discourses on the role of the multinational film, television, book and music industries. The issue was also taken up in a 1982 UNESCO report in which the organisation voiced its concern about the increasing corporisation of cultural industries and the global spread of mainly Western cultural products. The report concluded that these processes have led to the gradual marginalisation of cultural messages that do not take the form of marketable commodities.

Critical theory is criticised for its emphasis on reason, and the ownership and control of the means of cultural production as the main factors that determine the activities of artists. Writers and artists have argued that creativity and cultural consumption can thrive simultaneously and independently, and that the production process is not as organised according to rigidly standardised procedures as propagated by the theorists of the Frankfurt School (Littlejohn \& Foss 2005; Thussu 2000).

\section{The public sphere}

Theories of the public sphere have been a major issue in media studies in particular (Duvenhage 2005; Thussu 2000). The concept of a 'public sphere' was developed by the German sociologist, Jürgen Habermas. As an exponent of the school of critical theorists, he also bemoans the standardisation, massification and automisation of the masses due to the manipulation of public discourse by bureaucratic and economic interests such as advertising, marketing and public relations.

The central concept of this theory, the public sphere, is defined as an arena where a community of individuals is drawn together by participating in rational-critical 
debate (Duvenhage 2005; Thussu 2000). It developed from the representative public sphere during the feudal era, to the bourgeois public sphere in the modern era. These developments happened against the background of the developing capitalist economy and the establishment of the bourgeois constitutional state, and reflect the changing power relations between the monarch and his/her subjects due to the democratisation of the state and the growth of capitalism. Society became separated from the ruler and/or the state and the private realm was separated from the public. The public sphere became the arena of contestation of the interests of the bourgeois civil society on the one hand, and the state on the other hand. It is here that the rules of exchange of social goods and ideas are debated and public opinion is formed. Habermas regards the modern public sphere as an institutional location where the formal claims of democracy are debated. Furthermore, participants also develop rational-critical practices through which reasonable citizens can critically challenge the norms of the state and its monopoly on interpretation and institutions. The press, political parties and parliament became the main vehicles of this public discourse.

The theory furthermore gives prominence to the role of information in the public discourse (Thussu 2000). Greater freedom of the press, the wider availability of printing facilities and the development of new technologies that reduce the production costs of printed material have all served to stimulate rational-critical debate. Habermas's idealised vision of the public sphere involves greater accessibility to information and an open debate independent of capitalist interests and/or state apparatus - rational argument should be the sole arbiter of any issue.

However, Habermas has identified a decline in the bourgeois public sphere due to historical and economic developments since the $19^{\text {th }}$ century. Especially in the $20^{\text {th }}$ century, the growing power of information management and the manipulation of public opinion through public relations, lobbying and advertising firms have resulted in contemporary debates becoming 'faked versions' of the true public sphere (Thussu 2000). Free and critical debate within the public sphere has also been undermined by intervention on the part of the state and other powerful interest groups, which manipulate public discourse and the social engineering of public opinion and cultural consumption (Duvenage 2005). The commercialised mass media (such as radio, television and the press) become the main instruments of manipulation due to the fact that they speak directly to consumers and ignore and sidestep the critical rational debate within the public sphere. Habermas identifies these changes as the 'refeudalisation' of the public sphere, where the public space has become a location for power displays - similar to those in medieval courts - rather than a space for critical debate.

Habermas also perceives refeudalisation in the commercialisation of mass media systems, which has resulted in mass media organisations becoming monopolistic, capitalistic institutions that promote capitalist interests only and no longer promote debate within 
the public sphere (Thussu 2000). Within the market-driven economy, the main concern of the mass media is to produce artefacts that appeal to the widest possible audience and generate maximum advertising revenue. Mass media products are consequently diluted to meet the lowest common denominator, such as sensationalist sex, scandals, celebrity gossip and action adventures, thus reinforcing the public's compulsion with constant consumption.

The concept of the public sphere has also proved to be useful in theorising the role of communication processes in democratisation, identity-related processes and globalisation (Bornman 2003; Thussu 2000). According to Habermas (2001), there is a close relationship between the public sphere created by the mass media (and the national press and public broadcasting in particular) and feelings of national consciousness and identification within the modern, democratised nation state. He perceives national consciousness as a modern form of social solidarity in contrast to so-called 'pre-modern' forms of social allegiance based on descent, culture, language and history. National consciousness and national identification are regarded as products of new forms of communication.

In recent years, due to the decline of the nation state, the formation of supra-national units (such as the European Union) and increasing globalisation, the idea of the public sphere has been expanded to find appropriate forms of political and social integration within a changing world order. Habermas (2001) envisions the formation of a European identity in a similar way that national consciousness has been forged in the traditional nation state. Communication plays a central role in this vision of European integration. Habermas regards it as necessary to create a Europe-wide public sphere embedded in a freedom-valuing culture supported by a liberal civil society. This view involves public communication that transcends the borders of nation states. However, rather than the establishment of a European public broadcaster, Habermas foresees the emergence of a European public sphere from existing national spheres opening to one another, yielding to the interpenetration of international communication. An important step would be for national media to cover controversial issues in other countries in order for various national public opinions to converge on the same set of issues. Such a 'discursive' democracy or identity would not be located in any single nation state or ethnic or cultural community, but in the discursive spaces of civil society.

Habermas (1999) furthermore foresees one or other form of global political unit or cosmopolitan government as a solution for the multitude of problems associated with globalisation (see p. 37). He believes that, as is the case with supranational units like the European Union, global integration requires a global political culture shared by all world citizens. Thussu (2000) points to the fact that the globalisation of the media and of communication has indeed given rise to a so-called global public sphere, where issues of international importance - such as environmental degradation, human rights and gender equality - are articulated in the global media. 
Theories of the public sphere have also met with criticism (Duvenhage 2005; Thussu 2000). Firstly, they are criticised for their overridingly male, European and bourgeois emphases. The thesis of the refeudalisation of the public sphere has also been criticised for being one-sided and presenting an overly pessimistic view of modern society. The mediasation of modern culture can also not be regarded as refeudalisation. In contrast, the development of the media and ICTs has created new opportunities for the production and diffusion of images and messages - that is information - on an international scale. The refeudalisation theory also treats media users as passive consumers who are manipulated by clever techniques and numbed into the acquiescent consumption of mass media content. The emphasis on rational-critical debate and the neutralising effects of national consciousness, as well as European and global identities, furthermore points to the avoidance of and/or inability to deal with identity politics and concerns of difference. The public sphere has nevertheless proved to be a useful concept to explain and understand the effects of both national and international communication.

\section{Cultural studies}

Cultural studies is another theoretical tradition closely related to the critical tradition of the Frankfurt School, as well as to Gramsci's theory of hegemony (Littlejohn \& Foss 2005; Thussu 2000). The tradition had its origins at the Centre for Contemporary Cultural Studies in Birmingham, England, with Stuart Hall as its leading scholar. Preston (2005) views the cultural studies approach as a reaction against the holistic focus of structural and production-oriented analyses of political and economic power relationships, as represented in debates regarding the MacBride report, dependency theory, political economy and similar approaches. Instead of focusing on either the media or the audience, cultural studies tend to focus on communication as a cultural process. Broader issues of culture - instead of media or ICTs, institutions or power relations - are therefore the main foci of interest.

This multidisciplinary enterprise is therefore mainly interested in the ideologies that dominate a culture and has been focusing on cultural change on the basis of culture itself (Rantanen 2005; Thussu 2000). It is consequently predominantly populist in nature, in contrast to the intellectualism of the critical school. The main interests of cultural theorists have been the textual analysis of media texts - especially television texts - as well as ethnographic research. Of particular importance is Hall's model of the encoding and decoding of media messages and how these messages can be interpreted in different ways - from accepting the dominant meaning, negotiating with the encoding message or opposing or resisting the dominant viewpoint as embedded in the media text.

An important contribution of cultural theorists is the fact that they have created the possibility of studying all kinds of issues and subcultures that were excluded from earlier theories of international communication (Thussu 2000). Marginalised topics and 
politics of identity and difference related to race, ethnicity, gender and sexuality have consequently entered into the discourse. The emphasis on the marginalised, ordinary and popular has also provided an essential balance, with theories that focus on structural issues of power.

However, a major shortcoming of the work of cultural theorists is the fact it has an overriding British, European and/or Western perspective (ibid). Perceptions of the 'global' are often based on the study of migrant populations in Western countries. The cultural approach is also criticised from a Marxist perspective for its lack of classbased analyses, despite its emphasis on the 'popular'. Despite its shortcomings, the cultural approach has grown in importance and with its new-found interest in the 'global-popular', cultural studies represents a fast internationalising trend in theory and research.

\section{Theories of the information society}

One of the most recent theoretical strands to develop, is that of the 'information society'. The term emerged in the 1990s to coincide with the explosive development and global expansion of ICTs and the Internet in particular (Van Audenhove 2003; Thussu 2000). Proponents of the idea of an information society believe that new possibilities for the processing, storage and transmission of information have created an international information society that will, in the end, digitally link every home, office and business via the Internet - the network of all networks. These networks are the information highways that represent the infrastructure of the information society.

Central to theories on the information society is the conceptualisation of information in economic terms (Jimba 1998; Thussu 2000). Information is regarded as a commodity that represents a key strategic resource in the international economy. The power, status and level of development of nation states, organisations, collectivities and individuals are largely determined by their access to and ability to control and/or dominate information highways. Economic growth is furthermore perceived as a function of the spread of information technologies throughout the economy and society (Van Audenhove 2003). The growing informatisation and interconnectedness of economies have furthermore contributed to the integration of national and regional economies, thereby resulting in the creation of a global economy. Thus information has created both a new social and economic order.

Researchers and analysts such as Daniel Bell, Wilson Dizard, John Naisbitt and Alvin Toffler hold that society has moved through three stages, namely the agricultural age, the industrial age and, finally, the information age - the so-called 'third wave' (Straubhaar \& La Rose 1997). Bell (1973) argues that the information age is not merely characterised by the use of more information, but that a qualitatively different type of 
information has become available (Thussu 2000). The trilogy The information age by the Spanish theorist, Manuel Castells, represents a further significant input in theorising the information society (Castells 1996, 1997, 1998). Castells uses the term 'network society' where information technology forms the core driver of a new information technology paradigm, and argues that informational capitalism is increasingly operating on a global basis through exchanges by means of electronic linkages between circuits (linking local, regional and national information systems). These linkages bypass the authorities of nation states and play a central role in establishing regional and supranational units. Thus a new kind of relationship between economy, state and society is emerging.

Most proponents assume that the processes associated with the global spread of ICTs and the creation of an information society will have positive social and economic consequences as they will, among others, raise productivity; spread information and promote knowledge; foster the democratisation of society; and in general enhance quality of life (Van Audenhove 2003; Webster 1995). However, current theoretical contributions on the information society are criticised on various accounts. They are, among others, accused of simplistic technological determinism that tends to ignore the social, economic and political dimensions of technological innovation.

Another contentious issue in discourses on the information society is the so-called 'digital divide' or the information-rich versus information-poor debates (Arunachalam 1999). Disparities between the centre and the periphery with regard to access to ICTs (and therefore also to information highways) are believed to have far-reaching implications for developing countries and make it more difficult for them to compete with the developed world on various levels, and to participate in the information society. Thus the North-South disparity remains a central focus in debates on international communication (Hamelink 1994).

\section{Globalisation}

The discourse on globalisation is one of the latest - and probably most important and wide-ranging - theoretical debates to have emerged in international communication. According to Rantanen (2005), studies on globalisation started to emerge in the early 1900s - initially within the fields of geography and social science - from where the concept spread to other disciplines and, among others, also to media studies and international communication. Some theorists hold 'globalisation' to be the key concept when it comes to understanding changes within human society going into the third millennium (Thussu 2000).

Giddens (in Rantanen 2005) identifies three phases in discourses on globalisation. In the first phase the main point of contestation was whether or not globalisation exists. In 
the second phase it was no longer a question of whether or not globalisation exists, but rather what its consequences are. Currently we are entering a third stage, where debates address the responses necessary to counteract the negative consequences of globalisation. However, Rantanen (2005) points to the fact that considerations of the consequences of globalisation have already been imbedded in even the earliest conceptualisations of the concept.

Despite its popularity, 'globalisation' remains a contested topic. A review of some of the well-known general definitions reveals that theorists do indeed integrate the phenomenon with its consequences (Rantanen 2005). For example, Giddens (1990) refers to the intensification of social relations on a global scale and the fact that local events are influenced by what happens in distant locations. Thompson (1995) emphasises the growing interconnectedness of parts of the world that gives rise to complex forms of interaction and interdependency; while for Robertson (1992) globalisation means the intensification of an awareness of the world as a whole. The idea of complexity, as indicated by Thompson (1995), is also emphasised by Servaes, Lie and Terzis (2000) and Tehranian and Tehranian (1997) who distinguish vertical and horizontal dimensions of globalisation. The horizontal dimension refers to the progressive compression of temporal and spatial disparities culminating in the world becoming a single system. The vertical dimension involves the apparently contradictory trends towards homogeneity, synchronisation, integration and universalism versus the propensity for localisation, heterogeneity, diversity and particularism (Bornman \& Schoonraad 2001).

Many analysts prefer, on the other hand, to divide conceptualisations and theories of globalisation into economic, political and cultural globalisation (Rantanen 2005). Economic globalisation is often regarded as the driving force behind the entire globalisation process (Waters 1995). Within a liberal context, it is interpreted as the development and fostering of international economic integration and the spread of global capitalism - pan-capitalism, as some commentators have labelled it (Tehranian 1999; Thussu 2000). This conception denotes a qualitative shift from a largely national to a globalised economy where the economies of nation states are largely subordinate to transnational processes and transactions, and markets play a key role at the expense of nation states. The demise of the Soviet Union and Eastern bloc, the shift from public to private sector capitalism and the international trend towards liberalisation and privatisation have all contributed to the acceptance of the capitalist market as the global economic system (Thussu 2000).

Closely related to conceptions of economic globalisation are theories on political globalisation that focus largely on the changing position and role of the nation state (Bauman 1998; Waters 1995). Due to the internasionalisation of global economic activities and other transnational processes, the authority, legitimacy and sovereignty of the nation state are believed to be under constant threat. The borders of nation states 
have become increasingly porous, as governments are no longer able to control the flow of capital and information across their borders. The free flow of capital and information is furthermore progressively being exempted from the authority of the nation state, while global forces beyond its reach and control are imposing their laws and precepts on the planet. The nation state is furthermore being threatened by the formation of supranational units (such as the European Union and African Union), while ideas regarding some form of global government are frequently mentioned in order to address the consequences of globalisation (Habermas 1999). The nation state is consequently no longer the only viable political context for people to live in.

With regard to cultural globalisation, Bornman and Schoonraad (2001) distinguish between globalisation on the social and cultural terrains. Social globalisation is associated with the realisation - at least to a certain extent - of McLuhan's (1964) concept of the 'global village', in other words with the emergence of a borderless, non-spatial community. Although McLuhan's ideas are often criticised for being overidealistic (globalisation has not resulted in the disappearance of racial, cultural and other differences, as he prophesied) the reality of social globalisation is, among others, signified by the emergence of a 'global consciousness' and a global civil society which - as mentioned before - promotes worldwide cooperation to address global issues such as human rights, women's rights and environmental conservation (Thussu 2000).

Cultural globalisation is often perceived as just a new version of Western cultural imperialism, namely cultural homogenising due to the worldwide spread of the WesternAmerican lifestyle, values and consumer goods (ibid). A major consequence of the cultural levelling process is perceived to be that the spaces in which local communities can experience and live out their culture, become smaller and smaller. However, Appadurai (1990) argues that the effects of the multitude of forces that influence cultural globalisation are not simply homogenising, but rather they create new differences, contradictions and counter-tendencies as they encounter the different ideologies and cultural traditions of the world. A further consequence of these globalising forces is the weakening of the cultural coherence of nation states - yet another factor that threatens their authority and legitimacy. Whereas the MacBride report calls for the realisation of one world with many voices, Ayish (2005) points out that the dominance of American/ Western culture, combined with the revitalisation of ethnicity in the globalising world, is, in contrast, creating many worlds with only one dominant voice.

There can be little doubt that the (global) media and the worldwide spread of ICTs have made global interconnectedness - and thus globalisation - possible (Rantanen 2005; Tehranian 1999; Thussu 2000). It is therefore rather ironic that media and communication scholars have not been at the forefront of theorising globalisation. Most definitions and theories are extremely vague or do not mention the role of the media and communications at all. Media scholars furthermore tend to focus on national or 
local issues and therefore tend to miss the bigger picture of global interconnectedness and contribute little to the academic discourse on globalisation. When globalisation theorists do consider the role of the media and ICTs, they usually refer only to cultural globalisation. However, Rantanen (2005) objects to the tendency to limit the role of communication. He deems it necessary to acknowledge the role of the media and communications in general theories of globalisation, as well as in discussions of all the various domains - economic, political, social as well as cultural.

As already indicated, discourses and research on globalisation within international communication have been dominated by debates within the structuralism approach. These focus on whether the nature of the international flow of media and cultural products can be regarded as strictly one-way traffic and therefore as Western domination - in other words cultural imperialism (Thussu 2000). Post-structuralists, on the other hand, argue that counter-flow from the centre to the periphery, and between geocultural regions does exist. Moreover, cultural interactions are much more complex than proposed by imperialism and structuralist theories, with cultural flows moving in multiple directions and creating complex outcomes with regard to both homogenisation and heterogenisation (Hannerz 1997).

Rantanen (2005) points to some other interesting areas of theorising to highlight the role of communication in all spheres of globalisation. The first is the role, effects and farreaching consequences of mediated communication on all levels of society - locally as well as globally. Thompson (1995) points out that the development of global media and ICT networks have not merely created new networks for the dissemination of information across spatial boundaries, but have established new forms of action, interaction and social relations that are different from the face-to-face interactions which characterised human societies through the centuries. This is typified as 'mediated interaction', where the term 'mediation' can be defined as an active process of establishing relations between different kinds of being and consciousness that are invariably mediated (Williams 1977). Rantanen (2005: 8) presents the following alternative definition for globalisation, which takes into account the role of mediated communication in all domains: 'Globalization is a process in which worldwide economic, political, cultural and social relations have increasingly become mediated across time and space.'

Tomlinson (1994) also emphasises the different forms of experience that characterise globalisation. People experience the global in their everyday situated lives within the local sphere or, as stated by Giddens (1991), the local sphere is penetrated and influenced by distant events. Thus the nature of structures in the local sphere is not only a presentation of what is visible on the scene, but also reflects so-called 'distanciated' relations. Social relations are consequently disembedded from local contexts of interaction and stretch across time and spatial boundaries. According to Tomlinson there is a distinct difference between mass-mediated and non-mass-mediated experience: due to the establishment 
of global media networks, mass-mediated experience is often global and distanciated, whereas non-mass-mediated experiences concern the local sphere.

Rantanen (2005) draws the conclusion that globalisation changes people's lives and human society by introducing new forms of interaction and experience. Communication scientists can make a unique and invaluable contribution by theorising and researching the impact and consequences of these changes. In doing so, they should not restrict themselves to the cultural domain, but should explore the role of (international) communication on globalisation on all levels.

\section{CONCLUSION}

The overview presented in this article reflects the diversity of issues and foci of interest dealt with in international communication. It furthermore not only reflects the way in which discourses and theoretical paradigms have adapted to developments in global politics and the global economy, or the virtual explosion in the development and worldwide proliferation of ICTs in the last few decades.

In the end, good theory should lay the foundation for quality empirical research and provide a basis not only for explaining global communication processes and their effects, but also for making predictions with regard to future tendencies and proactive policy formulation. Most of the theories, paradigms and foci of interest deal with macro and meso issues, while little attention is given to the effects of global communication on micro levels. There is furthermore a tendency - probably due to the influence of media studies - to focus predominantly on cultural issues, thus neglecting the impact of global communication in other domains. A further question to be asked is whether the current preoccupation with information flows really creates a full understanding of global communication in the $21^{\text {st }}$ century. In this sense, a critical question for discussion is to what extent the theoretical paradigms, as discussed in this article, really cover the full complexity of global communication in the $21^{\text {st }}$ century.

\section{REFERENCES}

Appadurai, A. 1990. Disjuncture and difference in the global cultural economy. Theory, Culture \& Society 7: 295-310.

Arunachalam, S. 1999. Information and knowledge in the age of electronic communication: a developing country perspective. Journal of Information Science 25(6): 465-476.

Ayish, I. 2001. International communication in the 1900s: implications for the Third World. International Affairs 68(3): 487-510.

Ayish, M. 2005. From "Many voices, one world" to "Many worlds, one voice": reflections on international communication realities in the age of globalisation. JAVNOST - THE PUBLIC 12(3): 13-30. 
Bauman, Z. 1998. Globalization: the human consequences. Cambridge: Polity.

Bell, D. 1973. The coming of post-industrial society: a venture in social forecasting. New York: Basic Books.

Bornman, E. 2003. Struggles of identity in the age of globalisation. Communicatio 29(1\&2): 24-47.

Bornman, E. and N. Schoonraad. 2001. Globalisation and international communication: an introduction. In International communication: only study guide for COM305-C. E. Bornman, P. Fourie, Z. Lesame and N. Schoonraad (eds), 1-50. Pretoria: Department of Communication, University of South Africa.

Boyd-Barrett, O. 1977. Media imperialism: towards an international framework for the analysis of media systems. In Mass communication and society. J. Curran, M. Gurevitch and J. Woollacott (eds), 116-135. London: Edward Arnold.

Castells, M. 1996. The information age: economy, society and culture, volume 1: The rise of the network society. Oxford: Blackwell.

Castells, M. 1997. The information age: economy, society and culture, volume 2: The power of identity. Oxford: Blackwell.

Castells, M. 1998. The information age: economy, society and culture, volume 3: End of millennium. Oxford: Blackwell.

Chase-Dunn, C. and T.D. Hall. 1993. Comparing world-systems: concepts and working hypotheses. Social Forces 71(4): 851-886.

Collins English Dictionary. $2^{\text {nd }}$ ed. 2006. Glasgow: HarperCollins Publishers.

Duvenhage, P. 2005. Habermas, the public sphere and beyond. Communicatio 31(1): 1-12.

Fourie, P.J. 2003. The future of public service broadcasting in South Africa: the need to return to basic principles. Communicatio 29(1 \& 2): 148-181.

Frederick, H.H. 1993. Global communication \& international relations. Belmont, CA: Wadsworth.

Freire, P. 1974. Pedagogy of the oppressed. New York: Seabury Press.

Galtung, J. 1971. A structural theory of imperialism. Journal of Peace Research 8: 81-117.

Giddens, A. 1990. The consequences of modernity. Cambridge: Polity.

Giddens, A. 1991. Modernity and self-identity: self and society in the late modern age. Cambridge: Polity Press.

Habermas, J. 1998. The European nation state: On the past and future of sovereignty and citizenship. Public Culture 10(2): 397-416.

Habermas, J. 1999. The European nation state and the pressures of globalization. New Left Review 235: 46-50.

Habermas, J. 2001. Why Europe needs a constitution. http://www.newleftreview.net/NLR24501. shtml (Accesssed 7 May 2003.)

Hamelink, C.J. 1979. Informatics: Third World call for new order. Journal of Communication 29: 144-148.

Hamelink, C.J. 1983. Cultural autonomy in global communications. New York: Longman.

Hamelink C.J. 1994. Trends in world communication - on disempowerment and self-empowerment. Penang: Southbound.

Hannerz, U. 1997. Transnational connection. London: Sage.

Jimba, S.W. 1998. Information technology, globalization and Africa's information development. OCLC Systems \& Services 14(2): 64-70. 
Lerner, D. 1958. The passing of traditional society: modernizing the Middle East. New York: Free Press.

Littlejohn, S.W. and K.A. Foss. 2005. Theories of human communication. $8^{\text {th }}$ edition. Thomson: Wadsworth.

Mansell, R. and U. Wehn. 1998. Knowledge societies: information technology for sustainable development. New York: Oxford University Press.

Masmoudi, M. 1979. The new world information order. Journal of Communication 29: 172198.

McLuhan, M. 1964. Understanding media. New York: Signet.

McPhail, T.L. 1981. Electronic colonialism: the future of international broadcasting and communication. Beverly Hills, CA: Sage.

Mowlana, H. 1996. Global communication in transition: the end of diversity? Thousand Oaks, CA: Sage.

Mowlana, H. 1997. Global information and world communication: new frontiers in international relations. Thousand Oaks, CA: Sage.

Mowlana, H and L.J. Wilson. 1990. The passing of modernity: communication and the transformation of society. New York: Longman.

Nulens, G. and L. Van Audenhove. 1998. The African information society: and analysis of the information and communication policy of the World Bank, ITU and ECA. Paper presented at the $12^{\text {th }}$ IAMCR Conference. Glasgow: Communication Technology Policy Section.

Preston, P. 2005. Globalisation, imperialism \& communication studies: from the MacBride report to world summit on the 'information society'. JAVNOST-THE PUBLIC 12(3): 31-46.

Rantanen, T. 2005. The media and globalization. London: Sage.

Robertson, R. 1992. Globalization: social theory and global culture. London: Sage.

Rogers, E. 1962. The diffusion of innovations. Glencoe, IL: Free Press.

Schoonraad, N., E. Bornman and Z. Lesame. 2001.The media and technology of international communication. In International communication: only study guide for COM305-C. E. Bornman, P. Fourie, Z. Lesame and N. Schoonraad (eds), 51-146. Pretoria: Department of Communication, University of South Africa.

Schramm, W. 1964. Mass media and national development: the role of information in the developing countries. Stanford, CA: Stanford University Press.

Shannon, T. R. 1996. An introduction to the word-system perspective. Boulder: Westview.

Servaes J. 1995. Development communication - for whom and for what? Communicatio 21(1).

Servaes J., T. Jacobson and S. White. 1996. Participatory communication for development. Acco: Leuven.

Servaes, J., R. Lie and G. Terzis. 2000. Introduction: International communication: from media imperialism to cultural globalisation. Study guide for Paper 1 of the Master's Degree of Arts in International Communication, Department of Communication, UNISA: Pretoria.

Stevenson, R.L. 1992. Defining international communication as a field of study. Journalism Quarterly 69(3): 543-553.

Stevenson, R.L. 1994. Global communication in the twenty-first century. New York: Longman.

Straubhaar, J. and R. LaRose. 1997. Communications media in the information society. Belmont, CA: Wadsworth. 
Tehranian, M. n.d.. Global communication and international relations: changing paradigms and policies. http://www.gmu.edu/academic/jips/vol2_1/Techrenian.htm (Accessed 1 May 2006).

Tehranian, M. 1999. Global communications and world politics: domination, development and discourse. Boulder: Lynne Riener.

Tehranian, M. and K.K. Tehranian. 1997. Taming modernity: towards a new paradigm. In International communication and globalization. A Mohammadi (ed), 119-167. London: Sage.

Thompson, J.B. 1995. The media and modernity. Cambridge: Polity.

Tomlinson, J. 1994. A phenomenology of globalisation? Giddens on global modernity. European Journal of Communication 9(2): 149-172.

Thussu, D.K. 2000. International communication: continuity and change. London: Arnold.

Thussu, D.K. 2005. From MacBride to Murdoch: the marketisation of global communication. JAVNOST - THE PUBLIC 12(3): 47-60.

Van Audenhove, L. 2003. Theories on the information society and development: recent theoretical contribution and their relevance for the developing world. Communicatio 29(1\&2): 48-78.

Van Dijk, J. 1999. The network society. London: Sage.

Waters, M. 1995. Globalization. London: Routledge.

Webster, F. 1995. Theories of the information society. London: Routledge.

Williams, R. 1977. Marxism and literature. Oxford: Oxford University Press. 